\begin{tabular}{|l|l|l|l|l|l|l|}
\hline InterteXto & Uberaba & UFTM & $\begin{array}{l}\text { v. 1 } \\
\text { n. } 2\end{array}$ & p. 96-113 & 2008 - jul. / dez. & ISSN 1981-0601 \\
\hline
\end{tabular}

\title{
TRADIÇÃO E RUPTURA EM LAVOURA ARCAICA
}

\author{
TRADITION AND RUPTURE IN LAVOURA ARCAICA
}

\author{
Virgínia Celeste Carvalho da Silva ${ }^{1}$
}

\begin{abstract}
Resumo
Gaston Bachelard faz uma análise fenomenológica da imagem da Casa: como ela está impregnada por uma parcela de humano - o que the confere significações além de sua existência material - e como a sensação do sujeito ante esse local tem uma parcela constitutiva na construção do poético. Ele propõe uma topoanálise: reflexão sobre a espacialidade, ou seja, como no poético a verticalidade e a horizontalidade espaciais implicam uma simbologia da alma, do espírito e da consciência humana. A partir dessa leitura, pretende-se estudar a representação da Casa no romance Lavoura arcaica de Raduan Nassar. Percebe-se que a construção ficcional dá-se de forma dupla: uma casa símbolo da tradição e outra, em negativo, da ruptura.
\end{abstract}

Palavras-Chave: Espaço; Imagem; Poético; Ficção.

\begin{abstract}
Gaston Bachelard makes a phenomenological analyzes of the image of the House: how it is impregnated by a human being parcel - what confer to it, the meanings beyond its material existence - and how the sensation of the person before this place has a constituent parcel in the construction of poetical. He considers one topoanalysis: reflection on the spatiality, that is, as in the poetical the verticality and the horizontality of the spaces implies on a symbolism of the soul, the spirit and the human being conscience. From this reading, we intended to study the representation of the House in the romance Lavoura arcaica, by Raduan Nassar. One perceives that the fictional construction is made in a double form: a house symbol of the tradition and another one, in negative, of the rupture.
\end{abstract}

Key-Words: space; image; poetical; fiction.

\section{Introdução}

Ao passar de uma leitura descompromissada para uma análise crítica, percebe-se o quanto analisar uma obra literária é sempre uma escolha, se não ingrata, difícil; dificuldade que só cresce a cada releitura feita (um paradoxo:

\footnotetext{
${ }^{1}$ Virgínia Celeste Carvalho da Silva. Endereço: Rua José Domingos Regueira, 46, Areias, 50860-030, Recife, Pernambuco. Email: vcellestte@gmail.com. Mestranda em Teoria da Literatura pelo Programa de Pós-Graduação em Letras da Universidade de Pernambuco.
} 


\begin{tabular}{|l|l|l|l|l|l|l|}
\hline InterteXto & Uberaba & UFTM & $\begin{array}{l}\text { v. } 1 \\
\text { n. } 2\end{array}$ & p. 96-113 & 2008 - jul. / dez. & ISSN 1981-0601 \\
\hline
\end{tabular}

por outro lado, só com releituras é que se pode ter firmeza nas afirmações críticas). Fazer um recorte teórico, eleger categorias, definir análises, apesar de serem etapas necessárias, parecem não dar conta da totalidade artísticoliterária. Lança-se, então, apenas um olhar crítico - tímido, ante a grandiosidade de determinadas obras - que busca apreender, por meio da análise da construção narrativa, significados tanto de cunho estético quanto social.

A preocupação inicial, na leitura de Lavoura arcaica, era desenvolver um estudo semiológico sobre o espaço - sua construção, importância e como ele se conjuga com os demais aspectos romanescos. Entretanto, com uma leitura imanente do texto, seria muito fácil este ensaio tornar-se um "leito de Procusto", deixando de lado aquilo que seria o mais "belo", por assim dizer, no livro: a imagem poética. Imagens espaciais que possibilitaram unir, ao estudo semiológico, uma preocupação fenomenológica, baseada na Poética do Espaço, de Gaston Bachelard.

Dessa forma, o objetivo geral das presentes linhas é, após discutir os pressupostos teóricos, demonstrar como a construção do espaço ficcional se conjuga com as demais categorias narrativas, influenciando e sendo influenciado por elas. Nessa conjugação, nota-se que o espaço ficcional de Lavoura arcaica é "duplo": ganha dimensões semânticas distintas de acordo com a ótica das duas personagens principais. Paralelamente, observar-se-á o quanto a linguagem utilizada, peculiarmente poética no que diz respeito à criação das imagens espaciais, dá margem à leitura fenomenológica.

Decerto esta análise está longe de ser definitiva. Há outros elementos importantes no romance que não serão trabalhados aqui, como, por exemplo, a influência da cultura árabe ou mesmo, no âmbito da linguagem, um estudo aprofundado sobre a construção das imagens que não são espaciais. Todavia, com este ensaio, espera-se oferecer uma análise coerente.

\section{Fundamentação teórica: preocupações semiológicas}




\begin{tabular}{|l|l|l|l|l|l|l|}
\hline InterteXto & Uberaba & UFTM & $\begin{array}{l}\text { v. } 1 \\
\text { n. } 2\end{array}$ & p. 96-113 & 2008 - jul. / dez. & ISSN 1981-0601 \\
\hline
\end{tabular}

Para a semiologia, como explica Samuel Rogel (1998, p.110), o literário se constitui por uma operação mimética que converte, para o nível do imaginário, a relação existencial do homem com o mundo, por meio da ficcionalidade do espaço, das personagens e do acontecimento. Estas três categorias narrativas seriam, então, representações sígnicas da realidade objetiva no nível discursivo.

Por ser um investimento semiológico, o processo ficcional de tais categorias é incorporado ao fio narrativo como lógica estruturante. Conforme esse investimento, são distinguíveis três padrões: a narrativa de semiotização do espaço, a narrativa de semiotização da personagem e a narrativa de semiotização do acontecimento (ROGEL, 1998, p. 111). Seguindo essa perspectiva, observa-se que na primeira categoria citada, há uma sobreposição do espaço narrativo sobre o acontecimento e a personagem e, por mais que esta procure resgatar a dinâmica estruturante, para projetar-se fora da lógica imposta pelo espaço, não conseguirá. Por outro lado, na segunda categoria, a sua subjetividade é a dinâmica que estrutura a narrativa: o espaço e o acontecimento estão submetidos à sua lógica significante. E, por fim, na narrativa de semiotização do acontecimento, as ocorrências e ações irrompem independentes da lógica significantes da personagem e do espaço. Nessa última, o espaço tenta "codificar" o acontecimento e o personagem tenta "convertê-lo" em sua experiência subjetiva, porém acabam submetidos à lógica estrutural da proposição de realidade. Assim, a objetividade do espaço fragmenta-se, enquanto a experiência existencial do personagem projeta-se no vazio (ROGEL, 1981, p. 112).

Entender a divisão acima apresentada como uma tabela apriorística na qual se encaixam perfeitamente todas as narrativas modernas é tão ingênuo quanto pensar que apenas em um narrativa de semiotização do espaço é que se pode analisá-lo. É certo que diversos movimentos literários e, por conseguinte sua crítica, privilegiavam este tipo de narrativa - como a escola 


\begin{tabular}{|l|l|l|l|l|l|l|}
\hline InterteXto & Uberaba & UFTM & $\begin{array}{l}\text { v. } 1 \\
\text { n. } 2\end{array}$ & p. 96-113 & 2008 - jul. / dez. & ISSN 1981-0601 \\
\hline
\end{tabular}

naturalista, por exemplo - , pois ela se inspira no ideário positivista de que o homem era produto de seu meio.

Contudo, em Lavoura arcaica, narrativa contemporânea publicada em dezembro de 1975, há uma relação dialética entre personagem e espaço — relação na qual o tempo parece ser o mediador - que se torna difícil encaixála em uma denominação sem correr o risco de generalizações ${ }^{2}$. Como essa relação dialética estrutural é motivada por uma social, é importante olhar para a obra de maneira integrada, considerando tanto sua especificidade de construção literária quanto seu diálogo com a realidade sócio-cultural; ou seja, é preciso ver o "externo não como causa, nem como significação, mas como elemento que desempenha certo papel na constituição da estrutura, tornandose, portanto, interno" (CANDIDO, 1976, p. 4). Dessa forma, se há uma assimilação das relações socioculturais na estrutura das narrativas, torna-se necessário compreender quais possibilitaram a construção de um espaço "duplo" na obra em questão. E, para verificar o processo de "internalização sociocultural" na construção narrativa, como observa Schwarz (1987, p. 140), deve-se "ler o romance sobre fundo real e estudar a realidade sobre fundo de romance".

\section{A importância do espaço no romance}

Mieke Bal (1999, p. 132) afirma que, contraditoriamente à importância que desempenha nas narrativas, há poucos estudos relevantes sobre 0 espaço. Afirmação esta também feita por Antonio Dimas (1987, p. 35) e que aplicada à literatura brasileira soa mais estranha, visto que esta passa por períodos recorrentes de "naturalismo" ${ }^{3}$, nos quais tal aspecto narrativo ganha

\footnotetext{
${ }^{2}$ Este ponto será retomado no capítulo destinado à análise narrativa.

${ }^{3}$ A idéia de uma estética naturalista recorrente é de Flora Süssekind (1984, p. 40-60), explanada no ensaio "Uma ideologia estética: o naturalismo", no qual ela afirma que os movimentos literários dos anos de 30 e 70, do século passado, embora tenham suas especificidades, retomam a ideologia da escola do século 19 .
} 


\begin{tabular}{|l|l|l|l|l|l|l|}
\hline InterteXto & Uberaba & UFTM & $\begin{array}{l}\text { v. } 1 \\
\text { n. } 2\end{array}$ & p. 96-113 & 2008 - jul. / dez. & ISSN 1981-0601 \\
\hline
\end{tabular}

força. Entretanto, como já afirmado anteriormente, não são apenas em narrativas de semiotização do espaço que se pode analisá-lo, afinal, seja diluído ou fundamental, seja exterior ou interior, ele se encontra em todas as narrativas conjugado com o tempo e a personagem. Hoje é claro que não é mais possível uma análise espacial cujo foco é demonstrar o grau de veracidade topográfica ao ambiente real representado; é necessário que haja uma especulação funcional dessa representação no conjunto da obra.

De certa forma, no nível sintático, o espaço está em dependência constante com a focalização narrativa e com o ponto de vista escolhido pelo narrador. Ele é quem tece a caracterização espacial; essa fornece ao leitor, por meio das relações perceptíveis com o espaço, uma carga de significação simbólica (espaços fechados, amplos, soturnos, festivos, etc.). Assim, em uma narração, na qual o autor é onisciente, é provável que o narrador dê as caracterizações espaciais ao leitor antes que as personagens as conheçam; já em uma narrativa em primeira pessoa, com um "narrador testemunha", o leitor conhecerá o espaço junto ao narrador-personagem (menos em romances de memória, nos quais o narrador-protagonista detém o conhecimento do espaço).

Por outro lado, no nível semântico, o espaço se torna um objeto sobre o qual pode incidir diversas vozes sociais, logo sua significação pode variar de acordo com o discurso social que cada personagem representa. Ainda a este respeito, é válido lembrar que Bal faz diferenciação entre as instâncias "espaço" e "lugar"; este é apenas o local onde as personagens estão situadas e os acontecimentos ocorrem, enquanto aquele é configurado por meio da percepção das personagens.

Quanto à funcionalidade, para Bourneuf e Ouellet (apud DIMAS, 1982, p. 26), a descrição espacial desempenha alguns papéis que influenciam, principalmente, no tempo da narração e, consecutivamente, no ritmo da leitura. Assim, a descrição de uma paisagem após algum conflito poderá servir como um desaceleramento da história; por outro lado, se colocada anterior a um momento crítico, aumentará a expectativa ante os fatos. São utilizadas, 


\begin{tabular}{|l|l|l|l|l|l|l|}
\hline InterteXto & Uberaba & UFTM & $\begin{array}{l}\text { v. } 1 \\
\text { n. } 2\end{array}$ & p. 96-113 & 2008 - jul. / dez. & ISSN 1981-0601 \\
\hline
\end{tabular}

comumente, descrições para iniciar um romance, auxiliando a imersão do leitor no universo ficcional; por vezes elas são apenas caracterizações "francas" (LINS apud DIMAS, 1982, p. 16), que não apresentam outra funcionalidade senão descrever o "lugar" da ação. Contudo, por vezes, ela poderá ser uma caracterização "reflexa" e sua construção se faz pela ação das personagens no ambiente.

Assim como o tempo, o espaço possui duas maneiras de mensuração: uma convenção humana social, que atende a normas técnicas e a fórmulas matemáticas; e uma dimensão psicológica, cuja flexibilidade atende à experiência do sujeito. Por isso, nas narrativas, têm-se casos de "alargamento" espacial; uma análise microscópica dos componentes do cenário. Vê-se que, nesses casos, os objetos adquirem a imensidão do "eu" que os descreve: aquilo que, na vida, aparentemente não tem significância, em uma narrativa, pode tornar-se grandioso. $\mathrm{O}$ alargamento pode servir também para demonstrar uma "impossibilidade" do sujeito ante o mundo que o cerca: na estética naturalista, ilustraria o quanto o "eu" se encontra influenciado pelo meio do qual não pode fugir; em uma narrativa de suspense, o alargamento de um espaço sombrio aumentará a sensação de pavor das personagens.

\section{Em busca do poético}

Mais que uma criação narrativa, Lavoura arcaica é um investimento discursivo-poético. Assim o texto passa a ser não apenas a resultante de um processo mimético, mas recebe, pela voz do protagonista-narrador, uma carga lírica que age de forma centrípeta sobre a linguagem do romance. Embora não seja uma obra monológica, ou poética em sentido restrito, ela possui uma construção narrativa poética, pois as imagens espaciais ganham cargas semânticas distintas. Visto isto, é necessário, neste ensaio, definir e discutir quais as concepções de "poético" nele trabalhadas. Seguir-se-ão duas linhas teóricas distintas: a primeira concebida por Mikhail Bakhtin (1998), de base 


\begin{tabular}{|l|l|l|l|l|l|l|}
\hline InterteXto & Uberaba & UFTM & $\begin{array}{l}\text { v. } 1 \\
\text { n. } 2\end{array}$ & p. 96-113 & 2008 - jul. / dez. & ISSN 1981-0601 \\
\hline
\end{tabular}

lingüística e cultural; e outra trabalhada por Gaston Bachelard (2003), de cunho fenomenológico.

A escolha da teoria bakhtiniana se dá pela tentativa de analisar o gênero na obra em questão, pois se ela foi construída em forma romanesca, a carga lírica dá-lhe uma entonação poética. Para Bakhtin a diferença essencial entre o discurso romanesco e o poético dá-se na representação das vozes sociais. Enquanto no romance as representações dos objetos deixam transparecer o conflito social sobre eles, no poético a "palavra" do poeta tende a filtrar tais conflitos, transformando-os para sua própria linguagem:

Na obra poética, a linguagem realiza-se como algo indubitável, indiscutível, englobante. Tudo o que vê, compreende e imagina o poeta, ele vê, compreende e imagina com os olhos da sua linguagem, nas suas formas internas, e não há nada que faça sua enunciação sentir a necessidade de utilizar uma linguagem alheia, de outrem. (BAKHTIN, 1998, p. 94)

Embora Bakhtin reconheça que plurilingüismo social possa ocorrer na poesia lírica (1998, p. 87), é só no romance que se desenvolverá a interação dialógica do objeto com as vozes sociais que o perpassam. Isso porque mesmo quando quer dizer o que lhe é próprio, o prosador utiliza-se da linguagem de outro (BAKHTIN, 1998, p. 95). O discurso na poesia, em sentido restrito, por outro lado, é uma "criação artificial de uma nova linguagem poética" (BAKHTIN, 1998, p. 95); linguagem única que, de cetra forma, marginaliza tanto o passado histórico-social quanto o presente plurilíngüe do objeto discursivo, pois "daquilo que lhe é estranho, o poeta fala em sua própria linguagem" (BAKHTIN, 1998, p. 95).

Não se podem dissociar as considerações bakhitianas de seu contexto: ele criticava os pressupostos estilísticos que empregam aspectos próprios da poesia na análise do gênero romanesco, o estudo da obra literária como um todo fechado e a idéia de que o romance era um gênero menor por não ser poético, já que tratava de assuntos mais populares. Por isso, ele associa a poesia às forças centralizadoras ideológicas, às altas camadas sociais que 


\begin{tabular}{|l|l|l|l|l|l|l|}
\hline InterteXto & Uberaba & UFTM & $\begin{array}{l}\text { v. } 1 \\
\text { n. } 2\end{array}$ & p. 96-113 & 2008 - jul. / dez. & ISSN 1981-0601 \\
\hline
\end{tabular}

necessitavam de uma cultura unificada e vê o romance aberto às enunciações de outrem. Decerto há, na contemporaneidade, poemas que ratificam os valores ideológicos dominantes, porém é inegável que se faça poesia para controverter tais valores.

Tomando como ponto de partida tais considerações, pode-se especular a existência de obras que se encontram no limiar entre os gêneros romanesco e poético, visto que possuem tanto um movimento centrífugo quanto um movimento centrípeto sobre a linguagem. E Lavoura arcaica é, certamente, uma dessas obras, pois se percebe que os objetos são, ao mesmo tempo, uma arena na qual se digladiam pelo menos dois discursos (pai e filho) e que não se modificam nessa "luta" semântica.

No intuito de resolver tal ambigüidade ou, ao menos, de delimitar melhor o que é poético no romance estudado, é que se elegeu o estudo de Bachelard (2003) sobre o espaço. Em seu livro, A poética do espaço, o filósofo demonstra como as imagens poéticas são frutos de experiências humanas sobre os objetos, especificamente, sobre os lugares "habitáveis" que trazem em si a essência de "casa". Para tanto, ele explicita como esses "lugares felizes", recorrentes na poesia, são, por um lado, arquétipos adormecidos no inconsciente e, por outro, uma dupla novidade: a da produção, na subjetivação do objeto pela experiência do autor, e na repercussão, a transubjetivação dessa imagem pelo leitor:

Pede-se ao leitor de poemas que não encare a imagem como um objeto, muito menos como um substituto do objeto, mas que capte sua realidade específica. Para isso é necessário associar sistematicamente $\mathrm{o}$ ato da consciência criadora ao produto mais fugaz da consciência: a imagem poética. (BACHELARD, 2003, p. 4)

Bachelard vai, capítulo a capítulo, explicando como a espacialidade da casa, de seus cômodos e de imagens correlatas dão significação poética a vários textos; esses não são apenas versos, mas também "poemas em prosa" e cartas. A poeticidade da imagem estaria nos espaços de linguagem que cria, 


\begin{tabular}{|l|l|l|l|l|l|l|}
\hline InterteXto & Uberaba & UFTM & $\begin{array}{l}\text { v. } 1 \\
\text { n. } 2\end{array}$ & p. 96-113 & 2008 - jul. / dez. & ISSN 1981-0601 \\
\hline
\end{tabular}

retirando da linguagem um atomismo conceitual e arrastando consigo a imaginação criadora. Porque esse espaço "casa" é diversas vezes uma extensão do eu lírico, o filósofo o toma como imagem e não como metáfora: "a metáfora vem dar um corpo concreto a uma impressão difícil de exprimir" (2003, p. 82), enquanto a imagem guarda parte do ser do escritor, doando experiências desse ser ao leitor. Porém, mesmo que fale em experiências humanas, Bachelard, diferentemente da psicanálise, não resume a importância da imagem a estas, mas à sua produção. Para ele, a poesia está na sublimação total da experiência pela felicidade das palavras do poeta: "a poesia tem uma felicidade que the é própria, independentemente do drama que ela seja levada a ilustrar" (BACHELARD, 2003, p. 14).

Unindo estas duas visões sobre o poético, de cunhos teóricos distintos, serão levados em consideração, na leitura de Lavoura arcaica, os seguintes pressupostos: a imagem poética produz, na estilização da linguagem, uma força centrípeta, mesmo quando representa discursos diferenciados; ela, por ser um ato composicional de palavras, não pode ser resumida a arquétipos ou a sua motivação; também, por ser sempre um produto intersubjetivo, não se reduz ao discurso centralizador das classes dominantes nem tem uma relação meramente causal com as imagens que the antecederam, pois no processo de repercussão subjetiva, ela é sempre uma novidade.

\section{Duas casas: lugares, espaços, objetos}

"para onde estamos indo?" - não importava que eu, erguendo os olhos, alcançasse paisagens muito novas [...]: "estamos indo de volta pra casa" (NASSAR, 2003, p. 37)

Como já explicita o título, uma região rural é o "lugar" tematizado pelo romance Lavoura arcaica. As primeiras ações se passam em um quarto de uma pobre pensão, onde o protagonista - o filho pródigo, André - confessase a seu irmão Pedro, que tenta devolvê-lo ao seio da família. Essa confissão os leva, em pensamento, a outro local: a fazenda, o primeiro universo que lhes 


\begin{tabular}{|l|l|l|l|l|l|l|}
\hline InterteXto & Uberaba & UFTM & $\begin{array}{l}\text { v. 1 } \\
\text { n. } 2\end{array}$ & p. 96-113 & 2008 - jul. / dez. & ISSN 1981-0601 \\
\hline
\end{tabular}

é conhecido. Após a conversa, na qual memória e imaginação se misturam, o narrador-protagonista retorna ao lar deixado e revisita os lugares tecidos por seus atos de outrora: os aconchegantes refúgios de grossas raízes; a ruína da casa velha; o quadro de estacas, onde a cabra pacientemente mastigava; a já maculada capela.

A passagem de lugar (onde as ações ocorrem) para espaço (instância narrativa que, junto à personagem e ao tempo, estrutura o romance) ocorre no processo de subjetivação desses locais pelas personagens. Descrições da relação íntima entre personagens e ambientes, análise microscópica dos objetos, espaços destinados a cada membro da família são os mecanismos que criam as distinções topológicas e temporais da obra. Os divergentes olhares sobre o mesmo espaço o tornam duplo: um local sagrado e profano, símbolo de tradição e de ruptura. Por essa caracterização estrutural do espaço acompanhar o tema do livro, forma e conteúdo tornam-se, então, indissociáveis.

Dessa forma, a casa da fazenda, seus cômodos e suas adjacências vão ganhando dimensões semânticas distintas de acordo com a percepção que cada personagem possui. E é essa percepção que possibilita a divisão das personagens em dois grupos, apresentados, no excerto a seguir, pelas posições que cada personagem ocupa à mesa (símbolo de comunhão e harmonia, ao mesmo tempo em que representa a hierarquia de determinados membros sobre outros)

Eram esses os nossos lugares à mesa na hora das refeições, ou na hora dos sermões: o pai à cabeceira; à sua direita, por ordem de idade, vinha primeiro Pedro, seguido de Rosa, Zuleika, e Huda; à sua esquerda, vinha a mãe, em seguida eu, Ana e Lula, o caçula. $O$ galho da direita era um desenvolvimento espontâneo do tronco, desde as raízes; já o da direita trazia o estigma de uma cicatriz, como se a mãe, que era por onde começava o segundo galho, fosse uma anomalia, uma protuberância mórbida, um enxerto junto ao tronco talvez funesto pela carga de afeto; podia-se quem sabe dizer que a 


\begin{tabular}{|l|l|l|l|l|l|l|}
\hline InterteXto & Uberaba & UFTM & $\begin{array}{l}\text { v. } 1 \\
\text { n. } 2\end{array}$ & p. 96-113 & 2008 - jul. / dez. & ISSN 1981-0601 \\
\hline
\end{tabular}

distribuição dos lugares na mesa (eram caprichos do tempo) definia as duas linhas da família. (NASSAR, 2003, p. 157)

$\mathrm{O}$ arquétipo da hierarquia do lado direito (signo de sabedoria e força) sobre o esquerdo demonstra o grau de autoridade que o pai, seguido dos filhos mais velhos, exerce sobre os demais. A carga afetiva da mãe põe em risco a sobriedade necessária à organização cosmológica tradicional e conspurca os filhos a ela próximos. Assim, o lado esquerdo da mesa é a imagem "em negativo" do lado direito e é nessa relação que todo o romance se constrói. A carga poética se dá, nesse trecho, pela sobreposição, e depois fusão, da imagem da árvore sobre a imagem da mesa: o "eu" descreve a cena por meio de sua linguagem rural e através de sua relação subjetiva com o ato descrito.

Percebe-se que seguindo esta construção ambivalente, há espaços privilegiados aos olhos de cada grupo: ao primeiro são benfazejos lugares amplos, claros e de comunhão entre os membros; ao outro, recantos fechados, distantes e escondidos aos olhos dos demais são os preferidos. Também são os pertences do lar - móveis e utensílios - pontos de conflitos entre os dois discursos. Utilizados por ambos, eles servem tanto para corroborar com os princípios estabelecidos pelo legado familiar (1) quanto para contestá-los (2):

(1) [...] naquele dia, na hora do almoço, cada um de nós sentiu mais que o outro, na mesa, o peso da tua cadeira vazia (NASSAR, 2003, p. 25) ${ }^{4}$

(2) A prodigalidade sempre existiu em nossa mesa. (NASSAR, 2003, p. 158)

Nota-se, por estas passagens, que a construção discursiva não é metafórica, pois "a metáfora vem dar um corpo concreto a uma impressão difícil de exprimir" (BACHELARD, 2002, p. 82). Ela, embora mais próxima de uma poética metonímica, que toma significantes concretos para a representação de convenções abstratas, vai além. É uma fusão imagética criada pela experiência

\footnotetext{
${ }^{4}$ Tanto as aspas quanto os travessões, em todos os trechos citados da obra literária, são do autor.
} 


\begin{tabular}{|l|l|l|l|l|l|l|}
\hline InterteXto & Uberaba & UFTM & $\begin{array}{l}\text { v. } 1 \\
\text { n. } 2\end{array}$ & p. 96-113 & 2008 - jul. / dez. & ISSN 1981-0601 \\
\hline
\end{tabular}

do sujeito sobre os objetos, não apenas uma inversão. Com isso, família (abstrato) e matéria (concreto) fundem-se em um só corpo. Por conseguinte o despedaçar de qualquer utensílio remete à queda da família:

[...] eu e a senhora começamos a demolir a casa, seria agora o momento de atirar com todos os pratos e moscas pela janela o nosso velho guarda-comida [...] (NASSAR, 2003, p. 68)

Pode-se observar que há três tempos narrados: o da infância (memória distante); o da partida (memória recente) e o do regresso (presente diegético). A descrição espacial nestes três momentos não muda, são as mesmas árvores, a mesma terra, a mesma casa. Essa falta de variação do espaço ilustra que, apesar do tempo cronológico passar, o tempo psicológico do narrador não acompanha tal passagem. Isso demonstra também o quanto o campo possui seu "tempo" próprio, que parece não se importar com o ritmo frenético das alterações das grandes metrópoles.

\section{A estrutura da tradição}

A noção de que "a casa é o nosso canto do mundo. Ela é, como se diz amiúde, o nosso primeiro universo. É um verdadeiro cosmos" (BACHELARD, 2003, p. 24), em Lavoura arcaica, é latente na voz das personagens que representam o discurso da tradição. Mas ele vai além: fala da casa como cerne da família; local de um amor sagrado, imensurável e inquebrável, pois, nas palavras do pai:

Todos nós sabemos como se comporta cada um em casa: eu e tua mãe vivemos para vocês, o irmão para o irmão, nunca faltou, a quem necessitasse, o apoio na família! (NASSAR, 2003, p. 167)

A casa se estrutura, para o discurso da tradição, a partir do trabalho em conjunto, do diálogo contínuo e, principalmente, da paciência. Os valores cultivados são o autodomínio, o senso de dever e, acima de tudo, o amor. Tais 


\begin{tabular}{|l|l|l|l|l|l|l|}
\hline InterteXto & Uberaba & UFTM & $\begin{array}{l}\text { v. 1 } \\
\text { n. } 2\end{array}$ & p. 96-113 & 2008 - jul. / dez. & ISSN 1981-0601 \\
\hline
\end{tabular}

sentimentos são naturalmente gerados no galho direito da família; no entanto não produzem, no galho esquerdo, aos olhos da tradição, bons frutos. $O$ trabalho no campo - o plantio e a colheita - é tido como dádiva e sentido de vida. A partilha que é feita das tarefas também provoca a divisão dos espaços em ambientes femininos e masculinos:

[...] o pensamento ocupado com nossas irmãs em casa, perdidas entre os afazeres na cozinha e os bordados na varanda, na máquina de costura e os bordados na varanda, na máquina de costura ou pondo ordem na despensa [...] (NASSAR, 2003, p. 26)

Para os membros "tradicionais", a claridade nos ambientes e a clareza na linguagem são imprescindíveis para que a unidade da família seja mantida. A luminosidade dos espaços abertos demonstra como a tradição não tolera intimidades. Ela pede espaço aberto, onde as ações praticadas possam ser vistas por todos. Todo recolhimento é suspeito, pois a obscuridade do ambiente contagia os olhos límpidos e as palavras.

"as venezianas" ele disse "por que as venezianas estão fechadas?" (NASSAR, 2003, p. 16)

A língua familiar é monolítica e, como qualquer outro objeto da casa, deve obedecer a uma hierarquia cuja força centrípeta está na figura do pai. É do discurso paterno que devem partir os demais, sem, entretanto, contestá-lo. A representação textual dessa clareza lingüística dá-se com a reorganização frasal ocorrida no capítulo 25, quando pai e filho pródigo tentam, enfim, dialogar. Se os demais capítulos possuíam grandes orações apenas separadas por vírgulas, e os discursos alheios eram citados na sintaxe do narradorprotagonista, neste a sintaxe paterna se sobressai. Travessões são utilizados para demarcar territórios lingüísticos; sinais de pontuação oferecem ao texto um ritmo mais comedido, uma ordem de idéias até então não utilizada.

\section{A semente da ruptura}




\begin{tabular}{|l|l|l|l|l|l|l|}
\hline InterteXto & Uberaba & UFTM & $\begin{array}{l}\text { v. 1 } \\
\text { n. } 2\end{array}$ & p. 96-113 & 2008 - jul. / dez. & ISSN 1981-0601 \\
\hline
\end{tabular}

A despeito de habitarem a mesma casa e de cearem à mesma mesa, o significado destas ações não são iguais para todos os habitantes. Paralelamente a imagem tradicional de uma família patriarcalista, criou-se uma imagem inversa, "em negativo", que emprega novos significados aos "objetos familiares". Enquanto no olhar do pai essa inversão é causada pela falta de diálogo, para André reside, na frágil existência da palavra, a incompreensão:

- Toda ordem traz uma semente de desordem, a clareza, uma semente de obscuridade, não é por outro motivo que falo como falo. Eu poderia ser claro e dizer, por exemplo, que nunca, até o instante em que decidi o contrário, eu tinha pensado em deixar a casa; eu poderia ser claro e dizer ainda que nunca, nem antes e nem depois de ter partido, eu pensei que pudesse encontrar fora o que não me davam aqui dentro. (NASSAR, 2003, p. 160)

Com as mesmas imagens do discurso tradicional é que se constrói o novo discurso, isso demonstra que a degradação da personagem central, e de seus dois irmãos mais novos, não se deu pela modernização da vida. A mobília, por exemplo, continua a ser símbolo do peso familiar

\footnotetext{
"Não se constranja, meu irmão, encontre logo a voz solene que você procura, uma voz potente de reprimenda, pergunte sem demora o que acontece comigo desde sempre, componha gestos, me desconforme depressa a cara, me quebre contra os olhos a velha louça lá de casa"[...] (NASSAR, 2003, p. 17)
}

Entretanto um novo objeto é incorporado ao cenário; o corpo, que no discurso tradicional é negligenciado e reprimido, torna-se o eixo de significação. É em relação a ele que o ambiente se construirá: 


\begin{tabular}{|l|l|l|l|l|l|l|}
\hline InterteXto & Uberaba & UFTM & $\begin{array}{l}\text { v. } 1 \\
\text { n. } 2\end{array}$ & p. 96-113 & 2008 - jul. / dez. & ISSN 1981-0601 \\
\hline
\end{tabular}

Os olhos no teto, a nudez dentro do quarto; róseo, azul ou violáceo, o quarto é inviolável; o quarto é individual, é um mundo, quarto catedral, onde, nos intervalos da angústia, se colhe, de um áspero caule, na palma da mão, a rosa branca do desespero, pois entre os objetos que o quarto consagra estão primeiro os objetos do corpo [...] (NASSAR, 2003, p. 09)

Os espaços visitados e preferidos pelo "galho esquerdo" são refúgios. Porque não encontram em seu lar na "mesa familiar", cada um busca um local específico para ser sua própria "casa". Assim, quando o protagonista retorna ao lar, ao mesmo tempo em que o pai senta-se à varanda para que todos possam presenciar seu sofrimento, a mãe recolhe-se a seus aposentos para sofrer sozinha. A mesma fuga para recolher-se na solidão é feita por Ana, que se encarcerou na pequena capela para penitenciar-se. Já André sempre buscou na natureza o aconchego e o recolhimento que deveria encontrar em seu quarto:

Na modorra das tardes vadias na fazenda, era num sítio lá do bosque que eu escapava aos olhos apreensivos da família; amainava a febre dos meus pés na terra úmida, cobria meu corpo de folhas e, deitado à sombra, eu dormia na postura quita de uma planta enferma vergada ao peso de um botão vermelho; não eram duendes aqueles troncos ao meu redor, velando em silêncio e cheio de paciência meu sono adolescente? (NASSAR, 2003, p. 13)

Onde eu tinha a cabeça? Que feno era esse que fazia a cama, mais macio, mais cheiroso, mais tranqüilo, me deitando no dorso profundo dos estábulos e dos currais? (NASSAR, 2003, p. 50)

Mesmo que a natureza seja um espaço amplo, a relação de André com ela não é igual à relação de seu pai. Se este a cultiva, aquele não busca plantar seus frutos, quer colhê-los. Se o pai vê a natureza de forma maternal, André "profana-a".

Mas são nos espaços não enxergados ou encobertos pela tradição que estava já plantada a semente da ruptura. Nesses locais, a vida seguia subvertendo as lições patriarcais, trocando as significações das palavras: 


\begin{tabular}{|l|l|l|l|l|l|l|}
\hline InterteXto & Uberaba & UFTM & $\begin{array}{l}\text { v. 1 } \\
\text { n. } 2\end{array}$ & p. 96-113 & 2008 - jul. / dez. & ISSN 1981-0601 \\
\hline
\end{tabular}

[...] alguma vez te ocorreu afundar as mãos precárias e trazer com cuidado cada peça ali jogada? Era o pedaço de cada um, eu te asseguro, as coisas exasperadas da família deitadas no silêncio recatado das peças íntimas ali largadas [...] (NASSAR, 2003, p. 44)

Entretanto chega um momento - o do incesto - que a casa da família não mais acomoda essa "inversão" de valores. Por isso surge, na narrativa, outra casa; um espaço — também "em negativo" — onde as personagens podem vivenciar o proibido. É na inserção de Ana neste cenário que se tem a consolidação primeira da quebra total de valores. Por um momento, na perspectiva de André, aquela casa poderia consolidar-se, deixando de ser uma sombra nefasta da casa familiar.

No entanto, no final do livro, vê-se o quanto a degradação de valores já estava presente no pai, de forma sufocada ou até mesmo inconsciente:

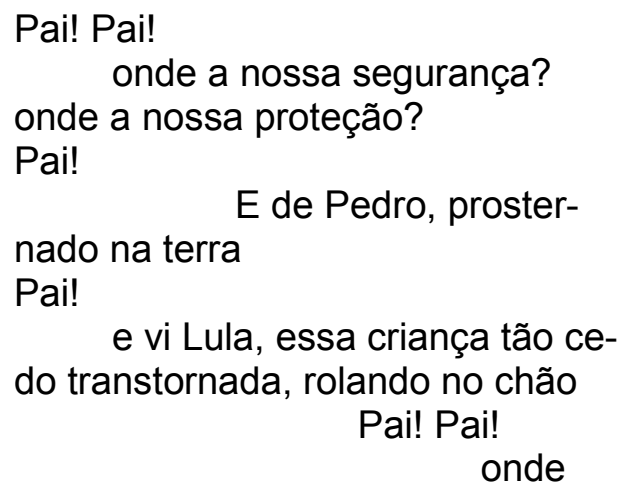

a união da família?

Pai! (NASSAR, 2003, p. 194)

\section{Conclusão}

Nesse trabalho tentou-se evidenciar a importância da construção espacial no romance Lavoura arcaica, sua conjugação com as demais categoriais narrativas - tempo e personagem - e como ele constrói a significação do todo romanesco. Foi percebido que o espaço ganha seu delineamento e suas cores com sua relação subjetiva com as personagens. 


\begin{tabular}{|l|l|l|l|l|l|l|}
\hline InterteXto & Uberaba & UFTM & $\begin{array}{l}\text { v. } 1 \\
\text { n. } 2\end{array}$ & p. 96-113 & 2008 - jul. / dez. & ISSN 1981-0601 \\
\hline
\end{tabular}

Com isso, percebeu-se a existência de dois espaços, de duas "casas", a partir de dois grupos discursivos: o da tradição e o da ruptura. Porque ambos os discursos recorrem às mesmas imagens para sua construção, têm-se, então, imagens invertidas, "em negativo". Os valores da ruptura nada mais são que o contrário dos valores apregoados pelo patriarcalismo.

Pelo estudo dos espaços e objetos privilegiados e menosprezados por cada grupo, percebe-se que esses valores invertidos não foram trazidos para o meio familiar, mas nele já estava a sua semente. Foi a repreensão e o silêncio sobre determinados assuntos que ocasionou o desmoronamento do lar.

De forma secundária, tentou-se demonstrar como há, no romance, traços do gênero poético. Eles são construídos com a fusão do "eu" das personagens no espaço. A linguagem empregada tende a ser monoestilística, pois o estilo discursivo do narrador atuou, em grande parte do romance, de forma centrípeta sobre os discursos alheios.

\section{Referências}

BACHELARD, Gaston. A poética do espaço. Trad.: Antonio de Pádua Danesi. São Paulo: Martins Fontes, 2005.

BAKHTIN, Mikhail. Questões de literatura e estética. $4^{\mathrm{a}}$ ed. Trad.: Aurora Fornoni Bernadini et al. São Paulo: Hucitec, 1998.

. Estética da criação verbal. $4^{\mathrm{a}}$ ed. Trad.: Paulo Bezerra. São Paulo: Martins Fontes, 2003.

BAL, Mieke. Narratology: introduction to the theory of narrative. Toronto: UTP, 1999. p. 132-142.

CANDIDO, Antonio. Ensayos e comentarios. Campinas/ México: Editora Unicamp/ Fundo de Cultura Econômica do México, 1995.

. Literatura e Sociedade, 8ª ed. São Paulo: T. A. Queiroz Editor, 1965.

DIMAS, Antonio. Espaço e romance. $2^{\mathrm{a}}$ ed., Série Princípios. São Paulo: Ática, 1987.

NASSAR, Raduan. Lavoura arcaica. São Paulo: Companhia das Letras, 2003. 


\begin{tabular}{|l|l|l|l|l|l|l|}
\hline InterteXto & Uberaba & UFTM & $\begin{array}{l}\text { v. } 1 \\
\text { n. } 2\end{array}$ & p. 96-113 & 2008 - jul. / dez. & ISSN 1981-0601 \\
\hline
\end{tabular}

RICOEUR, Paul. Tempo e narrativa. Tomo I. Trad.: Constança Marcondes Cesar. São Paulo: Papirus Editora, 1994.

ROGEL, Samuel (org.). Manual de teoria literária. $11^{\mathrm{a}}$ ed. Petrópolis: Vozes, 1998.

SCHWARZ, Robert. Que horas são? Ensaios. São Paulo: Companhia das Letras, 1987.

SÜSSEKIND, Flora. Tal Brasil, qual romance? - uma ideologia estética e sua história: o naturalismo. Rio de Janeiro: Achiamé, 1984. 